\author{
Sergey CHIMSHIT, \\ Liudmila GOLOVKOVA, \\ Alla YAKYMOVA, \\ Liliia DOBRYK
}

\title{
SPECIAL ASPECTS OF THE INFLUENCE OF MACROECONOMIC INDICATORS ON FORMATION OF THE BUDGETARY POLICY OF UKRAINE
}

\begin{abstract}
None of the states can fulfill its functions without the relevant and adequate financing which should complete the main task of the state - improvement of well-being of citizens and efficiency of the national economy. During the crisis,

(C) Sergey Chimshit, Liudmila Golovkova, Alla Yakymova, Liliia Dobryk, 2019.

Chimshit Sergey, Doctor of Economics, Associate Professor, Dnipro National University of Railway Transport named after Academician V. Lazaryan, Ukraine. ORCID 0000-0002-0861-2226. chimshit@gmail.com.

Golovkova Liudmila, Doctor of Economics, Professor, Head of Finance and Economic Security Department, Dnipro National University of Railway Transport named after Academician V. Lazaryan, Ukraine. ORCID 0000-0001-5473-6644. g.liudmila22@gmail.com.

Yakymova Alla, PhD in Finance, Associate Professor, Finance and Economic Security Department, Dnipro National University of Railway Transport named after Academician V. Lazaryan, Ukraine. ORCID 0000-0002-8261-4940. allayakymova@gmail.com.

Dobryk Liliia, PhD in Economics, Associate Professor, doctoral student, Finance and Economic Security Department, Dnipro National University of Railway Transport named after Academician V. Lazaryan, Ukraine. ORCID 0000-0002-3853-9285. liliadobrik@gmail.com.
\end{abstract}


structural and deep economic problems emerge, on which system decisions (instead of reactive and declaratory decisions) should be taken.

The paper deals with the influence of the economic policy of the state on its budgetary policy; analyzes the key macroeconomic problems of the national economy and defines the consequences; outlines strategic directions for the formation of the efficient budgetary policy of Ukraine.

It is established that the only way to overcome the crisis situation in Ukraine is the growth of GDP through the structural reforming of the economy and implementation of coordinated budgetary and monetary policy, shifting the focus from the fiscal orientation towards motivating one. The ultimate question lies in the growth of inclusive development index which would increase the level of competitiveness of the national economy and the standards of living in the globalization space.

\section{Key words:}

Budgetary policy; economic policy of the state; GDP; national economy; problems; inclusive development index.

JEL: E440 E690 H610.

\section{Introduction}

In the difficult economic conditions of the present time, which are strained even more by the European integration processes, the efficient financial policy is a basis for successful completion of introduced reforms. Furthermore, budgetary policy of the state is an integral part of the financial policy as a whole, so to fully understand the essence of the budgetary policy, its purpose and objectives it is necessary to determine the main principles of the state financial policy. 


\section{Problem statement}

Solving of the social and economic problems of the society is not possible without well-balanced and consistent economic policy of the state, which can be implemented only on condition of the sound budgetary policy that would ensure the optimal GDP distribution in the economy and promote increase of the Inclusive Development Index.

\section{Literature review}

Analysis of the latest research studies and publications. Significant contribution into development of the theory, methodology and mechanisms of the economic, fiscal policy and economic growth was made by the scientific works of well-known scientists J. M. Keynes, J. Schumpeter, J. Buchanan. Important role in studying of the budgetary policy as a socio-economic category and consideration of the existing problems was played by the scientists such as O. D. Vasylyk, V. H. Demianyshyn, M. M. Yermoshenko, I. O. Lunina, S. V. Mochernyi, Ts. H. Ohon, V. M. Oparin, I. Ya. Chuhunov, S. I. Yurii, F. O. Yaroshenko. The scientists I. K. Liutyi, O. Hordei, Z. Boiko, S. Yurii, Ye. Makarenko, V. Pikhotskyi and others paid attention to the peculiarities of evaluation of the quality and state of the budgetary policy.

In spite of the significant scientific results and theoretical achievements, a number of current issues require in-depth research, development and improvement, in particular, in the context of globalization impacts.

\section{Defining of uninvestigated parts of general matters}

On the assumption that primary objective of the state economic and, more specifically, financial policy, i.e. growth of GDP per capita, is not achieved in Ukraine, its fundamental reforming is needed. It is necessary to study new requirements and their influence on the formation and implementation of the weighted and effective, instead of declarative, budgetary policy. 


\section{Research objective}

Studying of the key issues of the national economy of Ukraine and their influence on the efficiency of the budgetary policy.

\section{The main provisions}

In the difficult economic conditions of the present time, which are strained even more by the European integration processes, the efficient financial policy is a basis for successful completion of introduced reforms. Furthermore, budgetary policy of the state is an integral part of the financial policy as a whole, so to fully understand the essence of the budgetary policy, its purpose and objectives it is necessary to determine the main principles of the state financial policy.

Fundamentally, financial policy of the state is a set of measures of the state related to organization and use of finances to ensure stable and balanced economic and social development of the society. Effectiveness of the viable financial policy of the state consists in the optimal distribution of the gross domestic product between the branches of the national economy, social groups of citizens, and territories aimed at growth of the national wealth. Traditionally, financial policy of the state includes certain components (Fig. 1).

In practical terms, tax policy and public spending policy are combined and defined integrally as a budgetary policy. Sometimes the national debt management policy is distinguished as an individual constituent part within the framework of the budgetary policy.

Efficient budgetary policy provides establishment of the sources of revenue generation for the state budget and identification of the priority areas of budget expenditures by the state. A separate issue of the efficient budgetary policy formation is the optimization of inter-budget relations between the individual parts of the budgetary system on the basis of setting the permissible limits of the budget disequilibrium. It is necessary to clearly identify the sources of financing of the budget deficit.

It is feasible to outline the financial policy principles: promotion of entrepreneurship, development of production, increase in occupational level; influence on the rational use of natural resources and technology development; provision of social guarantees for the different segments of the population. 
Fig. 1

Financial policy of the state

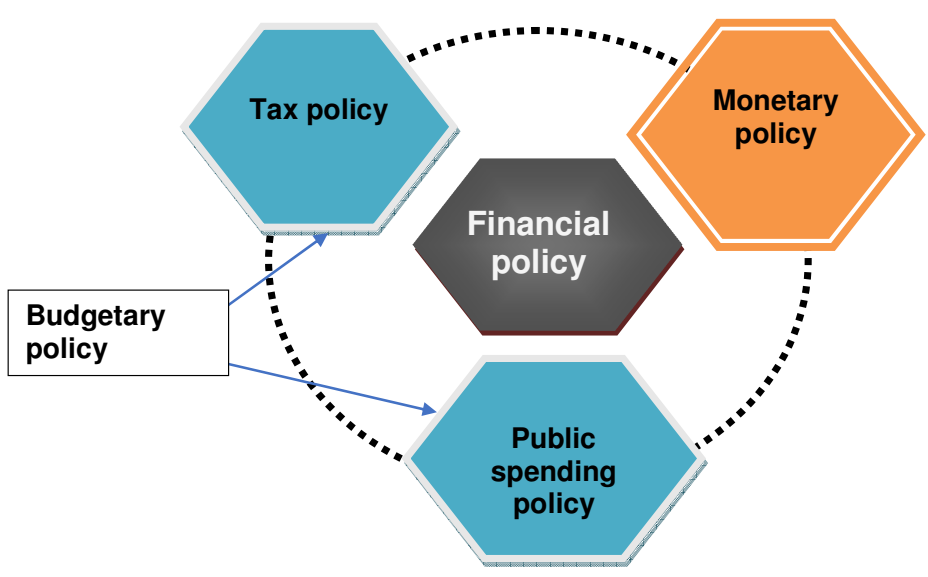

Under conditions of the sustainable development of the national economy, the state financial policy cannot give preference to the fiscal function of the state budget only; instead, it should focus on the regulatory function. It is important to note that the financial policy in itself flows from the economic policy of the state, being a tool of its implementation.

In the current context, it is necessary to clearly identify the principal direction of the national economy development from the perspective of creation of an effective mechanism for stimulation of the GDP growth and provision of deficitfree balance of the State budget. An important issue is the achievement of certain social standards through the prism of securing and regulating the employment of population.

Key indicator of the economic policy and results of its implementation is the real GDP of the country. GDP (or GDP per capita) and derived measures represent the main criterion of efficiency of the economy. One can talk a lot about certain reforms, processes in the economy, tendencies, and prospects, but the GDP indicator is a mirror reflecting the actual state of the economy as a whole and efficiency of the budgetary policy, in particular.

In this aspect, serious problems are observed in Ukraine. Unfortunately, we have no integrated, well-formed and suitable for implementation economic policy or the national strategy of economic growth. In 1990-ies various programs for economic formation and development were offered. Attempts to develop simi- 

on formation of the budgetary policy of Ukraine

lar documents were made later as well. Almost every political party offers something like that to its body of electors before the next parliamentary elections, as its proprietary solution. Formally, such policy now exists in the documentary form (the government for its election should propose a certain action plan, and that particular plan, if desired, can be called an economic policy - among the recent documents of this kind we can mention the Ordinance of the Cabinet of Ministers of Ukraine as of 03.04.2017 No. 275-p «On Approval of the Medium-term Plan of the Government's Priority Actions till 2020 and Plan of the Government's Priority Actions for Year 2017» but, unlike the Government's priority actions for year 2016 approved by the Ordinance of the Cabinet of Ministers of Ukraine as of 27.05.2016 No. 418-p, these plans were not even approved by the Verkhovna Rada of Ukraine) [1, 2].

Unfortunately, these are projects of unreasonable, declarative and populist nature. In addition, the document of this kind is intended for the period from one to three years as a maximum.

In this sense, it is important to understand the key principle of finances as a science. Finances represent just a superstructure above the real economy, i.e. the tool which services, accelerates and stimulates certain processes in the real economy, such as goods' and materials' flows. Finances in the economy should only serve the material flows; in essence, they take "a back seat» to the sphere of goods and services production. Finances cannot exist in themselves, just as, for example, money without turnover of the relevant goods and services has no value. Consequently, if there is no economic policy, target-oriented financial policy of the state cannot exist as well.

So, financial activity of the state exists, so to say, in itself. It follows that the state financial policy is very "short-sighted", i.e. designed for one year at most. Every year the Cabinet of Ministers of Ukraine («the CMU»), according to the requirements of the Budget code of Ukraine, proposes to the Verkhovna Rada («the VR») for consideration and approval «Principal directions of the budgetary policy for the next budget period», while the National bank of Ukraine («the NBU») develops "Key principles of the monetary policy for the next budget period». Only since 2017 , following the «Procedure of development of the Fundamentals of the monetary policy and control of its implementation» approved by the Resolution of the NBU as of 31.01.2017 No. 2-рд, the NBU develops the Strategy of the monetary policy for the medium-term (3-5 years) [3]. In reality, these documents are formal ones and almost do not carry the real weight since they are provided by the Budget code of Ukraine within its budget formulation process. Therefore, the relevant authorities are forced to develop and approve such documents, but all deadlines on their development are constantly disregarded.

As we can clearly see, the state financial policy, as a whole, is carried out by different state institutions (the monetary policy belongs to the sphere of the $\mathrm{NBU}$, while the budgetary policy is vested in the MFU) which do not always coor- 
dinate their purposes, objectives, and actions. Each of the institutions is focused on solving its own tasks. While the legislation provides an opportunity of interaction of the said agencies, their functioning is directed, so to say, inwards. All this does not contribute to achieving any long-lasting effect.

The economy in such conditions drifts according to the general pattern: if everything is good, it grows, otherwise it falls. Results of the year 2016 give the most striking example. Officially, according to statistics, Ukraine has the GDP gain and the government reports on the economic growth. But in reality there were no preconditions for this, except one: growth of world prices of products which are of strategic importance for the domestic economy.

The largest shares in the structure of general export of goods are as follows: products of agricultural sector and food industry (42\%); products of the metallurgical complex (23\%); machine-building products $(11.4 \%)$; mineral products $(9.6 \%)$ [4].

Fig. 2 shows the dynamics of world prices of wheat for recent years.

It is clearly seen that prices of this important product of the domestic economy fell since the second half of 2012 and reached its bottom mark in May-June 2016; after that, gradual price growth began.

Fig. 3.

Prices of another strategically important product (iron ore) are shown in

Fig 2

World prices of wheat in 2012-2017 [5]

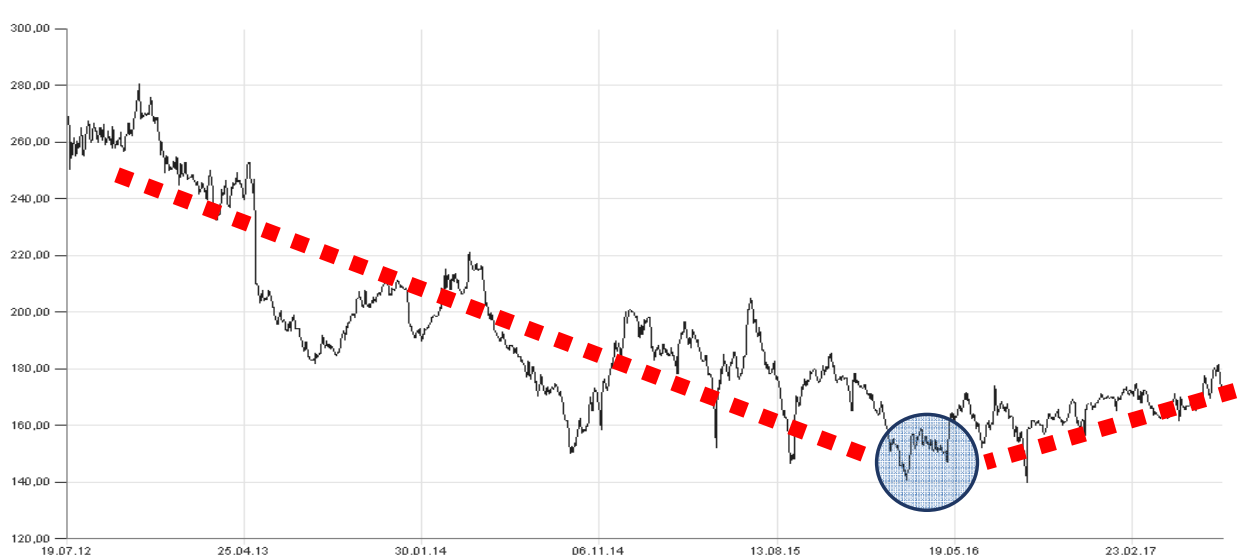


Fig 3

World prices of iron ore in 2012-2017 [6]

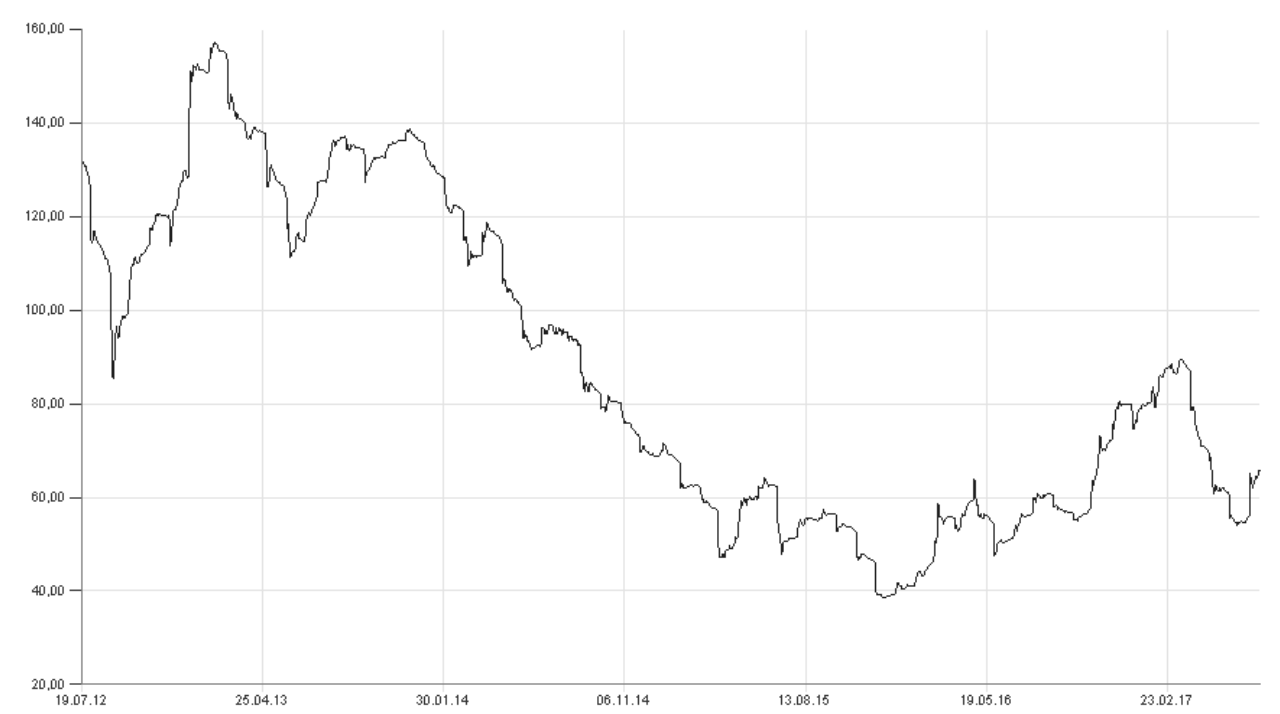

Similar situation is observed. Therefore, influence of the government, its actions and reforms is very conditional; it follows the external market situation. In fact, there is no economic and financial policy of the state.

Favorable (or unfavorable) external conditions have their impact only. But when such situation turns to the opposite side (as in 2012), Ukraine will face the serious economic problems again, in particular, in the budgetary sphere.

It is important to understand that the indicator of GDP is formed according to the principle of added value. Therefore, when at cost price (without salary) of 100 conventional units the products are sold for 150, we have added value of +50 . But if the same product unit with the same costs is sold, for example, for 175 conventional units, added value will be equal to +75 . When the same product with the same costs is sold at price of 130 , added value will make +30 only. Formally, one and the same product unit (without any added value) with the same costs can give different results. The price factor only works here, in the case of Ukraine it is the factor of world prices.

Ukraine has no protective mechanisms to resist these processes. The economy has a certain "ceiling" stipulated, first of all, by the technological level of development of the society, structure of the economy and its competitiveness; 
going beyond the limits at this stage of development is not possible. This limit is reached under the most favorable conditions in the foreign markets (as was the case, for example, in 2008-2009); in other cases the economy simply stalls, having no potential for growth. In 2012-2013 this limit was reached owing to capital investments for Euro-2012. Actually, the limit of the Ukrainian economy is approximately 185 bln. dollars (Fig. 4).

Fig. 4

GDP of Ukraine in \$ mln. [7]

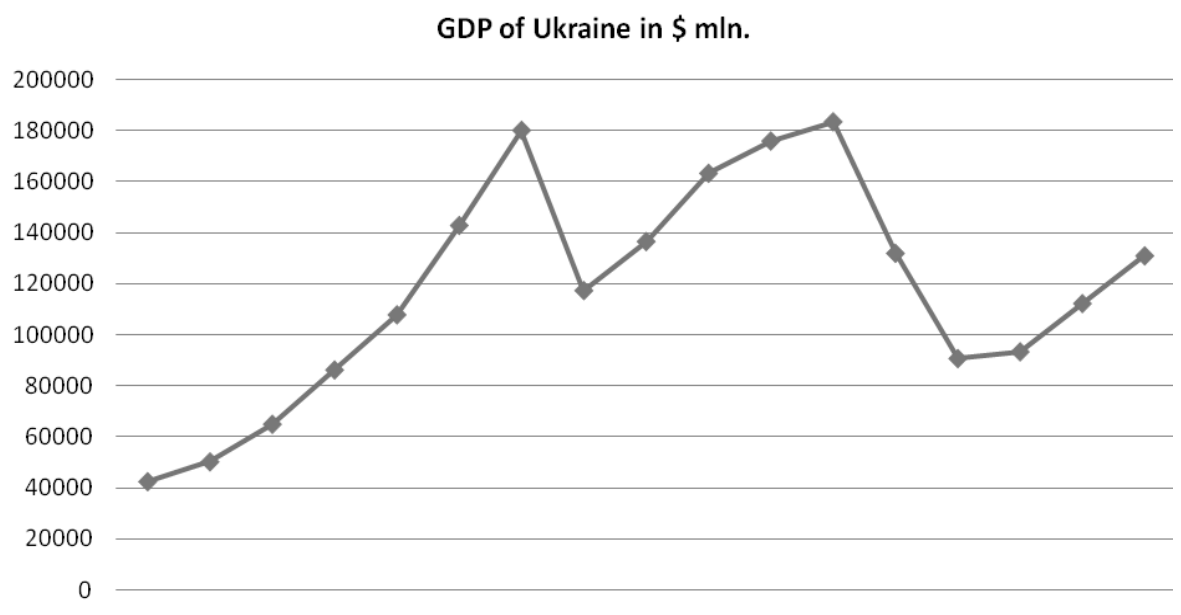

20022003200420052006200720082009201020112012201320142015201620172018

Fig. 4 shows the GDP of Ukraine in millions of dollars, since during all these years serious inflation processes took place, therefore, large difference exists between the nominal and actual GDP.

Of course, when we calculate the GDP of any country (except the USA) in dollars it is necessary to take into account the currency parity of purchasing power. If this aspect is taken into account, the values will be somewhat different, but the overall trend persists.

The reason of such impact of external factors lies in the GDP structure and the economic model of Ukraine. The share of export and import operations is 
about $50 \%$ (Table 1). Domestic economy is rather specialized one; it does not have wide coverage of goods and services.

Table 1

Structure of GDP of Ukraine by end use (UAH mln.) [8]

\begin{tabular}{|c|c|c|c|c|c|c|c|c|c|}
\hline \multirow{2}{*}{ Year } & \multicolumn{2}{|c|}{$\begin{array}{c}\text { Consumer } \\
\text { spending }\end{array}$} & \multicolumn{2}{c|}{$\begin{array}{c}\text { Gross capital } \\
\text { formation }\end{array}$} & \multicolumn{2}{c|}{$\begin{array}{c}\text { Export of goods } \\
\text { and services }\end{array}$} & \multicolumn{2}{|l|}{$\begin{array}{c}\text { Import of goods } \\
\text { and services }\end{array}$} & \multirow{2}{*}{$\begin{array}{c}\text { Nominal } \\
\text { GDP }\end{array}$} \\
\cline { 2 - 10 } & Amount & $\begin{array}{c}\% \\
\text { GDP }\end{array}$ & Amount & $\begin{array}{c}\% \\
\text { GDP }\end{array}$ & Amount & $\begin{array}{c}\% \\
\text { GDP }\end{array}$ & Amount & $\begin{array}{c}\% \\
\text { GDP }\end{array}$ & \\
\hline 2005 & 337879 & +76.5 & 99876 & +22.6 & 227252 & +51.5 & -223555 & -50.6 & 441452 \\
\hline 2006 & 424060 & +77.9 & 134740 & +24.8 & 253707 & +46.6 & -269200 & -49.5 & 544153 \\
\hline 2007 & 558581 & +77.5 & 203318 & +28.2 & 323205 & +44.8 & -364373 & -50.6 & 720731 \\
\hline 2008 & 758902 & +80.0 & 264883 & +27.9 & 444859 & +46.9 & -520588 & -54.9 & 948056 \\
\hline 2009 & 772826 & +84.6 & 155815 & +17.1 & 423564 & +46.4 & -438860 & -48.0 & 913345 \\
\hline 2010 & 914230 & +84.5 & 199918 & +18.5 & 549365 & +50.7 & -580944 & -53.7 & 1082569 \\
\hline 2011 & 1105201 & +83.9 & 282474 & +21.5 & 707953 & +53.8 & -779028 & -59.2 & 1316600 \\
\hline 2012 & 1269601 & +90.1 & 257335 & +18.3 & 717347 & +50.9 & -835394 & -59.3 & 1408889 \\
\hline 2013 & 1350220 & +92.8 & 228474 & +15.7 & 681899 & +46.9 & -805662 & -55.4 & 1454931 \\
\hline 2014 & 1409772 & +90.0 & 220968 & +14.1 & 770121 & +49.2 & -834133 & -53.2 & 1566728 \\
\hline 2015 & 1715636 & +86.7 & 303297 & +15.3 & 1044541 & +52.8 & -1084016 & -54.8 & 1979458 \\
\hline 2016 & 2018854 & +84.7 & 512830 & +21.5 & 1174625 & +49.3 & -1323127 & -55.5 & 2383182 \\
\hline 2017 & 2552525 & +85.6 & 618914 & +20.7 & 1430230 & +47.9 & -1618749 & -54.3 & 2982920 \\
\hline 2018 & 3196756 & +89.8 & 667953 & +18.8 & 1608890 & +45.2 & -1914893 & -53.8 & 3558706 \\
\hline
\end{tabular}

The national economy creates very low volumes of goods and services for domestic consumption. Actually, it still follows the Soviet economic model, when the consumer market was considered secondary. This shortage needs to be compensated by imports. In order to perform these operations, currency earnings are necessary. In their turn, currency earnings are possible in the conditions of significant export volumes.

The GDP calculations take into account net exports. Therefore, exports and imports overlap. However, imports are then reflected in consumer spending. The situation becomes more complicated, since the domestic economy fails to offer any unique and competitive products in foreign markets. The export products are fairly simple and standard goods and services with insignificant added value; furthermore, competition in these markets is very high. Besides, domestic companies have no factors of safety, i.e. prime cost and technological advantages of their products. They use, as a rule, outdated technologies corresponding to the technological modes 3-4. 
Therefore, Ukraine has extremely specialized economy, oriented towards foreign markets. Even insignificant fluctuations in the markets may have serious impact on the Ukrainian economy as a whole and budgetary policy, in particular, as a minimum, by $50 \%$.

In the mid- end of 1990-ies, after the Asian crisis, the disastrousness of the economic strategy focused on export-import operations was confirmed. But no conclusions were drawn in Ukraine, and the economic model remained the same. Fig. 4 proves the collapse occurring as a result of 2008 year crisis. Ukraine has lost about 35\% of its GDP. In 2014-2015 the economy of Ukraine actually returned to the level of 2005.

Another problem of the Ukrainian economic model is high importance of and constant pressure on the national currency rate. Any fluctuations in the national currency automatically affect both the volume of export-import operations, and also the growth of prices within the country. All imported goods (their volumes in country are extremely large, totaling over $55 \%$ ) increase in price. On the one hand, it leads to inflation processes and loss of purchasing power of citizens; on the other hand it causes falling of the country's GDP.

Theoretical approaches of economic science reflect that, on condition of the national currency exchange rate falling, domestic exporters receive significant economic benefits and may increase production and sales. However, since domestic enterprises (in their vast majority) are almost not competitive in the world markets, and their products have no unique properties, there is no growth in exports. On the temporary basis, as a result of lower competitiveness, imports reduction is observed; therefore, payments balance is temporarily stabilized easing the pressure on the national currency. But as the incomes start to grow, the situation is deteriorating again.

Consequently, on the basis of the economic policy, fiscal policy of the state is formed, which reflects total amount of financial resources available to the state; priorities in the sources of finances formation and areas of their use; creation of the finance management system; and mechanism for regulating and stimulating socio-economic processes through financial instruments.

Actually, the amount of financial resources available to the state is determined by the volume of its GDP. However, when speaking of GDP, it is important to understand one more important aspect, a model of financial system of the country. In other words, it means the method and source of formation of the country's GDP, as well as identification of dominating industries in the national economy. Financial system of Ukraine refers to the production type. The main financial resource of the country is formed in the production sector, construction, agriculture, transport and communications. Therefore, the indicator of industrial production index becomes very important. Unfortunately, we have seen steady tread towards decrease of this figure in Ukraine over the past seven years (Fig. 5). 
314 Sergey Chimshit, Liudmila Golovkova, Alla Yakymova, Liliia Dobryk Special aspects of the influence of macroeconomic indicators on formation of the budgetary policy of Ukraine

Fig. 5

Industrial production index (IPI) of Ukraine in 2010-2017 [9]

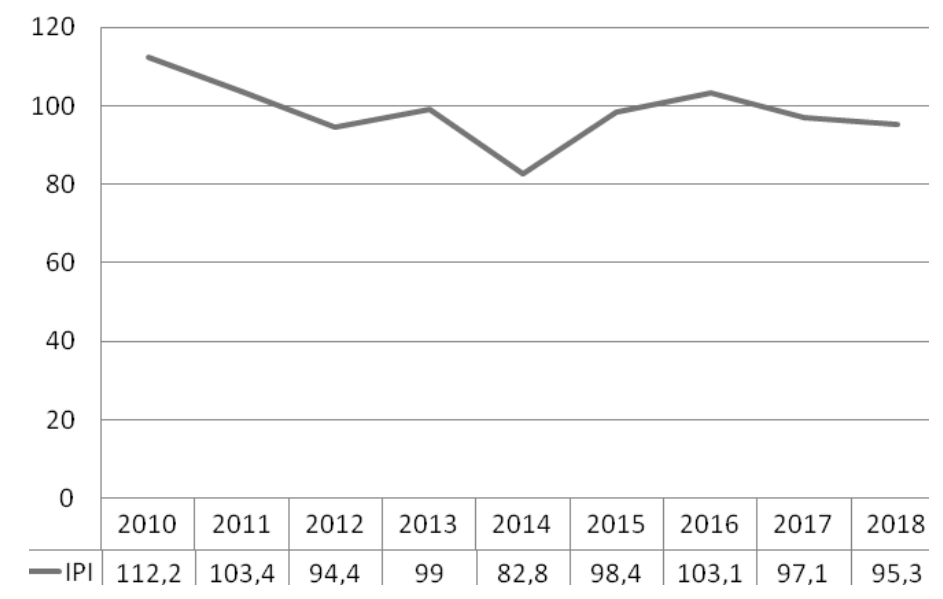

At the same time, shift of GDP from the sphere of production to the sphere of trade is observed; the country is producing less, and domestic enterprises give preference to reselling of imported goods over production. Besides, it is necessary to take into account that the largest industrial complexes, as elements of financial and industrial groups, bring almost all added value out of the country through offshore operations.

All this creates the situation when the state budget of Ukraine nominally increases, but really it receives less and less financial resources, so the state is forced to cut its expenses.

It is important to understand that the state as an institution does not create anything; it does not form a value. The state only collects a part of the GDP as taxes and redistributes it. Consequently, if the GDP is low, the revenues to the state budget are low as well. It is called a fiscal percent (Fig. 6).

In the event of any difficulties in the budgetary policy, changing of the situation (to replenish the state budget) is possible in two ways: increase in the tax burden, that is, in fiscal percent, or the GDP increase. In both cases, the state budget fullness will grow. The main task of the effective tax policy is to find the fiscal level at which the extensive reproduction and, accordingly, maximization of GDP growth are guaranteed. And fullness of the budget will be a causal inference of improvement of the macroeconomic performance. 


\section{Fig. 6}

Fiscal percent in Ukraine in 2008-2018 [8]

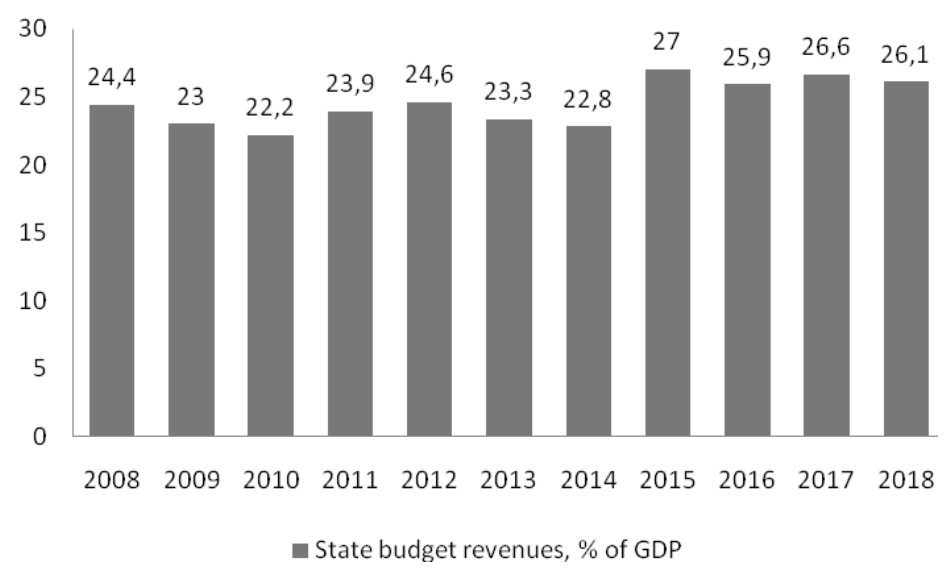

There is no other way. However, increase in the tax burden is not the best way to increase revenues to the state budget, as it demotivates business entities, since there is a certain limit after which the income begins to decrease at all, and the companies either go into the «shadows» or cease their activities at all. In addition, increase in the tax burden is not possible in the conditions of collapse and stagnation of the economy: it only increases the depth of the pit which the economy falls in. This thesis was confirmed in Ukraine in 2014-2016 when the state increased the tax burden on business in the times of financial and economic crisis.

In fact, GDP of the country and revenues to the state budget have very high, almost one hundred percent, correlation (Fig. 7).

Generally, it should be noted that in terms of the fiscal percent Ukraine is in the seventh ten of the world rating. Naturally, some countries feature the lower indicator, but some countries leave Ukraine behind.

In our opinion, the only rational and strategically justified way to increase revenues to the state budget is the GDP growth through effective implementation of the economic policy.

The concept of «fiscal percent» also helps to understand another aspect of the state financial policy, i.e. national debt management. Here it is necessary to return to the problem of the fall of the national currency exchange rate and its destructive impact on the budgetary policy. 
Fig. 7

\section{GDP interrelations with the revenues to the state budget [8]}

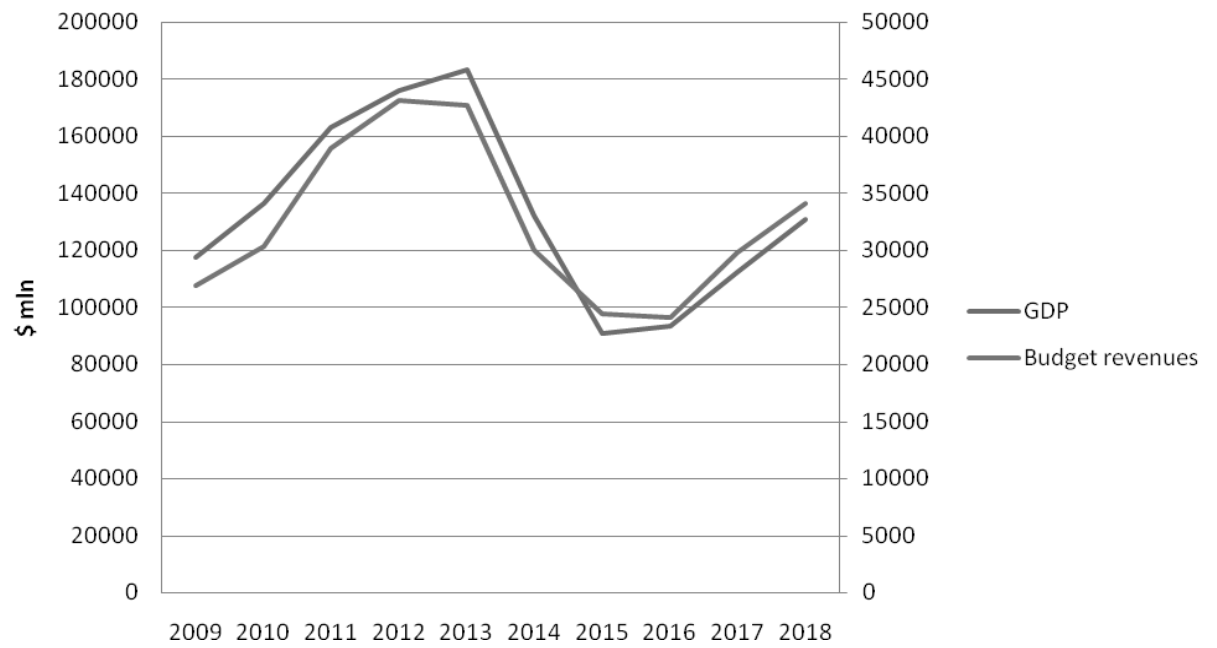

Currently, well-being of the society is evaluated not only by the GDP per capita and other criteria (which are combined as an integral indicator characterizing the standard of living for the society); for such evaluation the country's Inclusive Development Index is used as well. At the World Economic Forum in Davos it was mentioned as an alternative indicator in evaluation of the country's economic development [10]. In addition to GDP, it includes 11 measures combined into three groups: growth and development, inclusiveness, continuity of generations and sustainability of development.

Growth and development are directly related to the employment and scope of the national economy, the problems of which in Ukraine were outlined above. Inclusiveness of development of Ukraine correlates directly with the society wellbeing which is very sensitive to the wealth division. It, in turn, has its impact on the level of consumer demand, and, accordingly, development of entrepreneurship, financial capacity, scale of the shadow economy, and so on.

The factors of continuity of generations and sustainability of development in Ukraine include the environmental and demographic components, as well as the level of debt burden of the country on the future generations which is very critical in Ukraine. Let's consider this factor in more detail, since it is directly connected with the state financial policy of the past and present periods. 
Ukraine, like most other countries in the world, has the budget deficit for almost all years of its existence. Previously this deficit was covered by revenues from privatization, and then the state was forced to move to the lending mechanism. Due to the fact that internal resources of the economy are very limited, and vast majority of owners do not entrust their temporarily free financial resources to the state, Ukraine is forced to use the sources of external lending.

As we see from Table 2, the national debt of Ukraine in dollar terms (excluding year 2011) in recent years has growth substantially. But we cannot say this was a rapid growth. If you take 2011 as a reference point, then it is $+38 \%$ or an average $6.3 \%$ per year. At the same time, structure of the debt shows almost $2 / 3$ of the external debt.

In reality, situation is much more complicated (Table 3 ).

Table 2

Sovereign debt of Ukraine for the period from 2010 to 2018 (\$ $\mathrm{mln}$.) [8]

\begin{tabular}{|c|c|c|c|c|c|c|c|c|}
\hline \multirow{2}{*}{ Year } & \multicolumn{2}{|c|}{ Total debt } & \multicolumn{3}{|c|}{ External debt } & \multicolumn{3}{|c|}{ Internal debt } \\
\cline { 2 - 9 } & amount & $\begin{array}{c}\text { in- } \\
\text { crease, } \\
\%\end{array}$ & amount & $\begin{array}{c}\text { in- } \\
\text { crease, } \\
\%\end{array}$ & $\begin{array}{c}\text { share, } \\
\%\end{array}$ & amount & $\begin{array}{c}\text { amease, } \\
\%\end{array}$ & $\begin{array}{c}\text { share, } \\
\%\end{array}$ \\
\hline $\begin{array}{c}\text { as at } \\
01.01 .2010\end{array}$ & 39685 & & 26519 & & 67 & 13166 & & 33 \\
\hline $\begin{array}{c}\text { as at } \\
01.01 .2011\end{array}$ & 54289 & +36.8 & 34760 & +31.1 & 64 & 19530 & +48.3 & 36 \\
\hline $\begin{array}{c}\text { as at } \\
01.01 .2012\end{array}$ & 59216 & +9.1 & 37475 & +7.8 & 63 & 21741 & +11.3 & 37 \\
\hline $\begin{array}{c}\text { as at } \\
01.01 .2013\end{array}$ & 64495 & +8.9 & 38659 & +3.2 & 60 & 25836 & +18.8 & 40 \\
\hline $\begin{array}{c}\text { as at } \\
01.01 .2014\end{array}$ & 73078 & +13.3 & 37536 & -2.9 & 51 & 35542 & +37.6 & 49 \\
\hline $\begin{array}{c}\text { as at } \\
01.01 .2015\end{array}$ & 69795 & -4.5 & 38792 & +3.3 & 56 & 31003 & -12.8 & 44 \\
\hline $\begin{array}{c}\text { as at } \\
01.01 .2016\end{array}$ & 65506 & -6.1 & 43445 & +12.0 & 66 & 22060 & -28.8 & 34 \\
\hline $\begin{array}{c}\text { as at } \\
01.01 .2017\end{array}$ & 70971 & +8.3 & 45605 & +5.0 & 64 & 25366 & +15.0 & 36 \\
\hline $\begin{array}{c}\text { as at } \\
01.07 .2018\end{array}$ & 76305 & +7.5 & 48989 & +7.4 & 64 & 27316 & +7.7 & 36 \\
\hline $\begin{array}{c}\text { as at } \\
01.07 .2019\end{array}$ & 78323 & +2.6 & 50462 & +3.0 & 64 & 27861 & +2.0 & 36 \\
\hline
\end{tabular}


Table 3

Dynamics of cumulative national debt and GDP of Ukraine in 2010-2018 (UAH mln.) [8]

\begin{tabular}{|c|c|c|c|c|c|}
\hline & $\begin{array}{c}\text { Total na- } \\
\text { tional debt }\end{array}$ & $\begin{array}{c}\text { External } \\
\text { debt }\end{array}$ & Year & GDP & $\begin{array}{c}\text { National debt to } \\
\text { GDP ratio, \% }\end{array}$ \\
\hline $\begin{array}{c}\text { as at } \\
01.01 .2010\end{array}$ & 316885 & 211752 & 2009 & 913345 & 34.7 \\
\hline $\begin{array}{c}\text { as at } \\
01.01 .2011\end{array}$ & 432235 & 276746 & 2010 & 1082569 & 39.9 \\
\hline $\begin{array}{c}\text { as at } \\
01.01 .2012\end{array}$ & 473122 & 299414 & 2011 & 1316600 & 35.9 \\
\hline $\begin{array}{c}\text { as at } \\
01.01 .2013\end{array}$ & 515511 & 309000 & 2012 & 1408889 & 36.6 \\
\hline $\begin{array}{c}\text { as at } \\
01.01 .2014\end{array}$ & 584114 & 300025 & 2013 & 1454931 & 40.1 \\
\hline $\begin{array}{c}\text { as at } \\
01.01 .2015\end{array}$ & 1100564 & 611697 & 2014 & 1566728 & 70.2 \\
\hline $\begin{array}{c}\text { as at } \\
01.01 .2016\end{array}$ & 1572180 & 1042720 & 2015 & 1979458 & 79.4 \\
\hline $\begin{array}{c}\text { as at } \\
01.01 .2017\end{array}$ & 1929759 & 1240029 & 2016 & 2383182 & 81.0 \\
\hline $\begin{array}{c}\text { as at } \\
01.01 .2018\end{array}$ & 2141674 & 1374996 & 2017 & 2982920 & 71.8 \\
\hline $\begin{array}{c}\text { as at } \\
01.01 .2019\end{array}$ & 2168627 & 1397218 & 2018 & 3558706 & 60.9 \\
\hline
\end{tabular}

The external debt of Ukraine as at 01.01 .2014 is $37536 \mathrm{mln}$. dollars. This figure as at 01.01.2019 makes $50462 \mathrm{mln}$. dollars, so these values can be considered almost identical ones (the difference is $34 \%$ ). Money was borrowed in dollars and should be repaid in dollars. However, in the hryvnia equivalent the external debt as at 01.01.2014 is UAH 300025 million, and as at 01.01.2019 UAH 1397218 million, with the growth of 4.66 times. That is, the state actually did not borrow anything in addition, but its debt automatically increased more than three times. The problem is that Ukraine as a state is functioning in the hryvnia environment: the GDP is measured in hryvnias, taxes are collected in hryvnias, costs are stated in hryvnias, and so on. Owing to the fiscal percent, the state can collect in the form of taxes only a part of the GDP (again in hryvnias), but with the current rate of the national currency it is much lower. It follows automatically that solvency of the Ukrainian state has fallen catastrophically. In fact, it is necessary to raise $81 \%$ of the GDP to pay off the country's debts, without spending a dime for domestic needs. But the state can actually collect only about 
$33 \%$ of the GDP per year. So, to repay the debt sum it is necessary to use the budget of 2.5 years without any internal spendings.

It is possible to get new loans in order to repay the old ones. But since the loan stipulates a percent for use of funds, each time you have to borrow more and more. This financial spiral sooner or later leads to bankruptcy. You cannot increase taxes, or bear internal costs (the state as such simply ceases to exist); but the only way out is - increase of the GDP. If we talk about finances directly, then financial incentives for business entities are needed which would push them to more active production and sales of goods and services.

\section{Results and Discussion}

Financial policy of the state in itself flows from the economic policy, being a tool of its implementation.

Key indicator of efficiency of the economic policy and results of its implementation is the growth of real GDP of the country and increase of the level of the Inclusive Development Index.

Today there is no integrated, well-formed and suitable for implementation economic policy or the national strategy of the economic development in Ukraine.

Ukraine has extremely specialized economy, oriented towards foreign markets. Therefore, the GDP gain is very sensitive to the world prices of strategic products of the domestic economy, since the largest share in the structure of general export of goods is represented by products of agricultural sector, food industry and the metallurgical complex.

Therefore, external market conditions have their impact on the GDP growth, instead of implementation of the efficient economic and financial policy of the state. Furthermore, structure of the Ukrainian economy and its competitiveness create a limit which cannot be exceeded at this stage of development.

Historically, the model of Ukrainian financial system refers to the production type with the priority of fiscal taxes' function.

It should be noted that Ukraine faces an urgent issue of improving the efficiency of the national debt management, the main part of which is dollar debt; therefore falling of the national currency rate led to actual increase of the debt in hryvnia terms more than three times. This creates the catastrophic pressure on the future budget of Ukraine. In the context of deep systemic crisis, decline in production, impoverishment of the population and breakdown of creditors' confidence in the country, it may actually result in bankruptcy of the state, due to the lack of financial resources to fulfill its basic functions. 

on formation of the budgetary policy of Ukraine

Besides, shifting of the focus from production to commerce and extremely high level of shadowing of the economy in the current conditions leads to difficulties in the budgetary policy, which can be solved only by way of the GDP growth and increase of the Inclusive Development Index in Ukraine, but it is a subject of future research.

\section{References}

1. On Approval of the Medium-term Plan of the Government's Priority Actions till 2020 and Plan of the Government's Priority Actions for Year 2017. Ordinance of the Cabinet of Ministers of Ukraine as of 03.04.2017 No. 275-p. [Electronic resource]. - Access mode: http://zakon3.rada.gov.ua/laws/ show/275-2017-\%D1\%80

2. Program of activities of the Cabinet of Ministers of Ukraine approved by the Resolution of the Verkhovna Rada of Ukraine as of 14.04.2016 No. 1099-VIII [Electronic resource]. - Access mode: http://zakon2.rada.gov.ua/ laws/show/ 1099-19\#n7

3. Procedure of development of the Fundamentals of the monetary policy and control of its implementation approved by the NBU Resolution as of 31.01.2017 No. 2-рд [Electronic resource]. - Access mode: http://zakon3.rada.gov.ua/laws/show/vr002500-17

4. Information graphics on the link: http://bit.ly/2x2VCVS.

5. Analytical center «UkrAgroConsult» [Electronic resource]. - URL: http://www.ukragroconsult.com/news-main/zernovye/news-listing-extended/

6. Metallurgical Internet-portal «Territory of Steel»» [Electronic resource]. URL: https://www.steelland.ru/

7. Official portal of the State Statistics Service of Ukraine [Electronic resource]. - URL: http://www.ukrstat.gov.ua/

8. Official portal of the Ministry of Finance of Ukraine [Electronic resource]. URL: https://index.minfin.com.ua/

9. Ministry of Economic Development and Trade: Official web-site. [Electronic resource]. - Electronic data. - Kyiv: CMU. - Access mode: http://www.me.gov.ua

10. World Economic Forum «Electronic resource]. - URL: https://www.segodnya.ua/economics/enews/na-vsemirnom-ekonomicheskomforume-pridumali-alternativu-pokazatelyu-vvp-1108779.html. 